\title{
UPAYA PENINGKATAN NILAI TAMBAH PRODUK SAYURAN ORGANIK DI DESA CIBODAS KECAMATAN LEMBANG KABUPATEN BANDUNG BARAT
}

\author{
Rani Andriani Budi Kusumo, Anne Charina dan Agriani Hermita Sadeli \\ Program Studi Agribisnis Fakultas Pertanian Universitas Padjadjaran \\ E-mail': raniandriani081@gmail.com
}

\begin{abstract}
ABSTRAK. Pemerintah Kabupaten Bandung Barat menetapkan Desa Cibodas sebagai salah satu Desa Organik. Program Desa Organik saat ini lebih difokuskan pada kegiatan mendorong praktek pertanian yang ramah lingkungan. Kelompok PKK Desa Cibodas Kecamatan Lembang berupaya untuk mendukung gerakan Desa Organik dengan menciptakan nilai tambah dari produk sayuran organik yang merupakan salah satu komoditas unggulan di Desa Cibodas. Kegiatan pengolahan mie sayuran organik diharapkan dapat meningkatkan nilai tambah produk sayuran organik yang selaras dengan gerakan Desa Organik dan juga berpotensi meningkatkan pendapatan keluarga petani. Kegiatan Pengabdian Kepada Masyarakat ini bertujuan untuk: 1) Meningkatkan kesadaran masyarakat, khususnya mitra PKM mengenai peluang usaha pengolahan sayuran organik menjadi produk mie organik; 2) Berkembangnya gerakan Desa Organik di Desa Cibodas, dengan diversifikasi usaha produk sayuran organik. Metode pelaksanaan dari kegiatan ini adalah: 1) Pelatihan pembuatan mie berbahan baku sayuran organik; 2) Penyuluhan peluang usaha produk olahan sayuran organik; 3) Pendampingan pada mitra. Kegiatan PKM ini telah memberikan perubahan pada aspek pengetahuan dan keterampilan peserta dalam meningkatkan nilai tambah produk sayuran organik melalui kegiatan pengolahan mie organik. Melalui kegiatan PKM diperoleh inisiasi dari pihak Desa Cibodas untuk mengembangkan beragam produk olahan dari sayur organik sebagai produk unggulan Desa Cibodas.
\end{abstract}

Kata kunci: nilai tambah, pelatihan, pengolahan, sayur organik.

\section{AN ENHANCEMENT EFFORT OF ADDITIONAL VALUE ORGANIC VEGETABLE PRODUCTS IN CIBODAS VILLAGE, LEMBANG SUB-DISTRICT, BANDUNG BARAT DISTRICT}

\begin{abstract}
Cibodas Village is as one of Organic Village in Bandung Barat Regency. The Organic Village Program is currently more focused on promoting environmentally friendly agricultural practices. PKK Group endeavors to support the Organic Village movement by creating added value from organic vegetable product which is one of the leading commodities in Cibodas Village. Organic vegetable noodle processing activities were expected to increase the added value of organic vegetable products in harmony with the Organic Village movement and also potentially increase the income of farming families. Community Service Activities aims to: 1) Increase public awareness, especially PKM partners about the business opportunity of processing organic vegetables into organic noodle products; 2) Development of Organic Village movement in Cibodas Village, with diversification of organic vegetable products business. Method of implementation of this activity were: 1) Training of making noodles made from raw organic vegetables; 2) Extension of business opportunities of organic vegetable processed products; 3) Assistance to partners. This PKM activity has made changes in the knowledge and skills of the participants in increasing the added value of organic vegetable products through organic noodle processing. Through the activities obtained PKM initiation from the Village Cibodas to develop a variety of processed products from organic vegetables as superior products in Cibodas Village.
\end{abstract}

Key words: value added, training, processing, organic vegetable

\section{PENDAHULUAN}

Pertanian berkelanjutan merupakan tantangan dalam dunia pertanian, yang menuntut petani untuk memiliki perilaku usaha tani yang berbeda dan lebih baik terutama untuk aspek lingkungan. Salah satu sistem pertanian yang merupakan implementasi dari sistem pertanian berkelanjutan adalah sistem pertanian organik. Indonesia sebagai negara agraris memiliki peluang dan potensi besar untuk mengembangkan pertanian organik. Dengan memiliki 17 juta hektar lahan kosong dan masih luasnya pertanian tradisional yang dikelola tanpa menggunakan bahan sintetis, menjadi salah satu modal penting untuk mengembangkan pertanian organik. Berdasarkan data statisitik total luas area pertanian organic Indonesia tahun 2012 adalah 213.023,55 ha yang tersebar di 15 Provinsi di Indonesia (Zulvera, 2014).
Pemerintah pun mendukung trend pertanian organik dengan mengeluarkan kebijakan pemerintah yang disebut Go Organic 2010. Beberapa kebijakan lainnya yang tercantum dalam Program Nawacita diantaranya sampai dengan tahun 2020, pemerintah Indonesia mencanangkan pembentukan 1000 Desa Organik, yang terdiri dari 600 Desa Organik Pangan, 250 Desa Organik Horitkultura dan 150 Desa Organik Perkebunan. Desa Cibodas termasuk ke dalam salah satu desa yang terpilih sebagai Desa Organik Hortikultura. Pengembangan desa organik ini bertujuan mengubah perilaku mayarakat dari hulu sampai hilir dengan menerapkan aktifitas non kimiawi dalam usaha tani nya.

Sejauh ini di Desa Cibodas, sistem pertanian ogranik sudah diterapkan yang dipelopori oleh Kelompok Tani Mitra Tani Jaya. Kelompok tani ini sudah mampu memasok sayuran organik ke pasar modern di Kabupaten Bandung. Namun berdasarkan hasil penelitian di 
lapangan terdapat beberapa masalah yang dikemukakan oleh petani terkait sistem pertanian organik ini. Mereka berpendapat dengan sistem organik pendapatan mereka tidak berubah sama sekali dibandingkan ketika mereka menerapkan pertanian konvensional.

Karenanya melalui kegiatan Pengabdian Kepada Masyarakat ini, Tim PKM menawarkan solusi penciptaan nilai tambah dari sayuran organik melalui pengolahan mie organik. Jenis sayur organik yang dapat diolah menjadi mie diantaranya adalah bayam, sawi dan wortel organik. Akitifitas ini mendukung salah satu program desa organik yaitu untuk poin mengkonsumsi produk organik dalam menunjang kesehatan dan keamanan pangan. Kegiatan pelatihan pengolahan sayur organik bertujuan untuk meningkatkan pengetahuan dan keterampilan peserta, sekaligus menjadikan produk mie organik sebagai peluang usaha untuk meningkatkan pendapatan keluarga. Karena saat ini masyarakat semakin menyadari pentingnya menjaga kesehatan, sehingga mendoronng permintaan akan pangan organik.

\section{METODE}

Hasil yang diharapkan dari kegiatan PKM (Pengabdian Kepada Masyarakat) ini adalah meningkatnya pengetahuan dan keterampilan peserta dalam mengolah mie berbahan dasar sayuran organik untuk mendorong munculnya usaha baru berbasiskan olahan sayuran organik, sehingga bisa meningkatkan pendapatan masyarakat.

Peserta dalam kegiatan PKM ini adalah ibu-ibu anggota PKK Desa Cibodas Kecamatan Lembang sebanyak 30 orang. Adapun tahapan pelaksanaan dari kegiatan ini ditunjukkan dengan kerangka kerja pada seperti pada Gambar 1.

Tahapan kegiatan PKM ini dimulai dari tahapan persiapan dan perencanaan program. Tahap awal dari penyusunan program adalah menggali permasalahan dan kebutuhan masyarakat yang dilakukan melalui kegiatan FGD (Focus Grup Discussion). Dari kegiatan FGD diperoleh informasi bahwa Desa Cibodas sebagai desa yang terpilih untuk program Desa Organik ingin meningkatkan nilai tambah dari produk sayuran yang dihasilkan oleh sebagian penduduknya. Peluang pasar produk olahan sayuran cukup terbuka lebar di Desa Cibodas, karena selain pertanian, sektor unggulan di Desa Cibodas adalah sektor pariwisata. Banyaknya lokasi wisata di Desa Cibodas mendorong peningkatan jumlah wisatawan di Desa Cibodas. Harapan dari perangkat Desa Cibodas adalah terciptanya produk olahan dari sayuran yang dapat dijual ke wisatawan sebagai buah tangan khas Desa Cibodas.

Setelah diketahui permasalahan yang dihadapi masyarakat, selanjutnya disusunlah rencana kegiatan pelatihan yang dibuat dalam dua kali pelatihan, yaitu pelatihan pengolahan sayur organik menjadi mie organik serta pelatihan bagaimana menangkap peluang usaha produk olahan sayur organik.

Pelaksanaan kegiatan lebih banyak dilakukan dengan cara pelatihan atau workshop sehingga peserta dapat langsung melaksanakan praktek sehingga mereka dapat lebih mudah untuk menguasai materi yang akan diberikan.

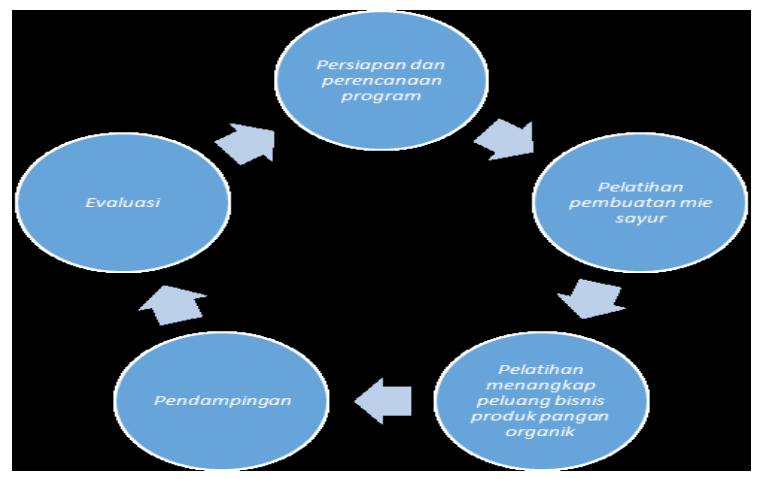

Gambar 1. Metode Pelaksanaan Kegiatan PKM

Hasil-hasil lain yang diharapkan adalah pemenuhan kondisi harapan agar peserta mengetahui dan pada akhirnya mengaplikasikan teknologiteknologi hasil penelitian yang ada, dan yang terlebih penting lagi adalah masyarakat dapat menciptakan produk olahan sayuran organik marketable sehingga dapat menjadi produk yang unggul dan menjadi unique selling points (USP), sehingga menghasilkan keunggulan bersaing (competitive advantage) (Subroto, 2014).. Dari sisi metode hasil yang diharapkan adalah keterampilan yang memadai bagi para peserta. Feder et al (2004) serta Godtland et al (2004) menyebutkan difusi teknologi akan terjadi jika peserta pelatihan berpartisipasi secara aktif dan mempunyai kepemimpinan yang kuat dalam menyampaikan opini (Feder dan Savastano, 2006).

\section{HASIL DAN PEMBAHASAN}

Program kegiatan pengabdikan kepada masyarakat diawali dengan koordinasi dengan ketua kelompok tani Mekar Tani Jaya (MTJ) dan aparat Desa Cibodas Kecamatan Lembang yang merupakan salah satu lokasi kegiatan penelitian Riset Fundamental Unpad (RFU). Koordinasi awal dilakukan untuk menggali permasalahan yang dihadapi masyarakat dan alternatif solusinya melalui kegiatan PKM. Selanjutnya koordinasi dilakukan untuk menentukan waktu pelaksanaan kegiatan PKM. Peserta kegiatan PKM ini adalah anggota PKK Desa Cibodas Kecamatan Lembang yang berjumlah 30 orang. Untuk menunjang penyampaian materi, panitia menggunakan alat batu seperti modul pelatihan. Peserta juga diajak mempraktekkan langsung materi pembuatan mie sayur yang telah dipaparkan oleh narasumber. Hasil pelaksanaan kegiatan PKM dapat dilihat pada tabel berikut: 
Tabel 1. Hasil Pelaksanaan Kegiatan Pelatihan Pembuatan Mie Sayur Organik

\begin{tabular}{|c|c|c|}
\hline No. & Program & Hasil \\
\hline 1 & Sosialisasi & $\begin{array}{l}\text { Sosialisasi Dilakukan melalui } \\
\text { penyampaian maksud dan } \\
\text { tujuan kegiatan secara langsung } \\
\text { pada aparat Desa Cibodas dan } \\
\text { kelompok tani MTJ }\end{array}$ \\
\hline 2 & $\begin{array}{l}\text { Identifikasi } \\
\text { Masalah }\end{array}$ & $\begin{array}{l}\text { - Permasalahan didapat dari } \\
\text { hasil penelitian hibah RFU } \\
\text { dan juga diskusi dengan aparat } \\
\text { Desa Cibodas }\end{array}$ \\
\hline 3 & $\begin{array}{l}\text { Identifikasi } \\
\text { Materi }\end{array}$ & $\begin{array}{l}\text { - Tersusun materi yang sesuai } \\
\text { bagi kebutuhan mitra dan } \\
\text { penyelesaian masalah } \\
\text { yang dihadapi mitra yaitu } \\
\text { khususnya mengenai } \\
\text { pengolahan sayur organik }\end{array}$ \\
\hline 4 & $\begin{array}{l}\text { Identifikasi } \\
\text { Peserta }\end{array}$ & $\begin{array}{l}\text { - Terdaftar calon peserta } \\
\text { pelatihan yaitu anggota PKK } \\
\text { Desa Cibodas dan anggota } \\
\text { kelompok tani MTJ } \\
\text { - Calon peserta adalah anggota } \\
\text { PKK yang belum memiliki } \\
\text { pengetahuan dan keterampilan } \\
\text { membuat produk olahan sayur } \\
\text { organik. }\end{array}$ \\
\hline 5 & $\begin{array}{l}\text { Identifikasi } \\
\text { Pemateri }\end{array}$ & $\begin{array}{l}\text { - Pemateri adalah staf pengajar } \\
\text { dari Prodi Agribisnis serta } \\
\text { praktisi di bidang pengolahan } \\
\text { produk pangan }\end{array}$ \\
\hline 6 & $\begin{array}{l}\text { Penyiapan Alat } \\
\text { Bahan }\end{array}$ & $\begin{array}{l}\text { - Tersedia alat dan bahan } \\
\text { penunjang efektivitas } \\
\text { pelatihan partisipatif }\end{array}$ \\
\hline 7 & $\begin{array}{l}\text { Identifikasi } \\
\text { Lokasi }\end{array}$ & $\begin{array}{l}\text { - Lokasi kegiatan dilaksanakan } \\
\text { di sekretariat kelompok tani } \\
\text { MTJ }\end{array}$ \\
\hline 8 & $\begin{array}{l}\text { Pelatihan } \\
\text { pembuatan mie } \\
\text { sayur organik }\end{array}$ & $\begin{array}{l}\text { - Tingkat partisipasi masyarakat } \\
\text { dalam pelatihan sangat baik, } \\
\text { hampir seluruh peserta yang } \\
\text { diundang datang } \\
\text { - Peserta sangat antusias karena } \\
\text { mendapat tambahan informasi } \\
\text { dan pengetahuan } \\
\text { - Dari hasil post test diketahui } \\
\text { terdapat peningkatan } \\
\text { pengetahuaan peserta } \\
\text { sebanyak } 95 \% \text {. } \\
\text { - Dari hasil post test diketahui } \\
\text { terdapat peningkatan } \\
\text { keterampilan peserta dalam } \\
\text { membuat mie organik } \\
\text { sebanyak } 90 \%\end{array}$ \\
\hline
\end{tabular}

Penjelasan:

1. Bagi Peserta (Anggota PKK)

a. Tingkat Partisipasi

Kegiatan pelatihan dilaksanakan dilaksanakan di secretariat kelompok tani MTJ Desa Cibodas Kecamatan Lembang. Lokasi tersebut dipilih berdasarkan pertimbangan:

- Mudah dijangkau oleh peserta

- Fasilitas yang terdapat di lokasi sangat menunjang kegiatan ceramah dan praktek pembuatan mie sayur organik.

- Kriteria tersebut menjadi dasar bagi tim PKM setelah melalui diskusi dengan aparat Desa Cibodas. Hampir seluruh peserta hadir dalam kegiatan pelatihan.

\section{b. Pengetahuan dan Keterampilan Peserta}

Hasil yang dicapai adalah terjadinya peningtan pengetahuan dan keterampilan peserta, yang diketahui berdasarkan hasil pre test dan post test. Pada awalnya, hanya $3,6 \%$ peserta pelatihan yang mengetahui cara membuat mie organik dan dapat membuat mie sendiri. Setelah diberikan materi, sebagian besar peserta $(96,4 \%)$ memahami cara membuat produk mie organik dan mengetahui peluang pasar produk olahan sayuran organik. Dari sisi keterampilan, setelah pelatihan $92,4 \%$ peserta dapat mempraktekkan pembuatan mie organik (Gambar 2).

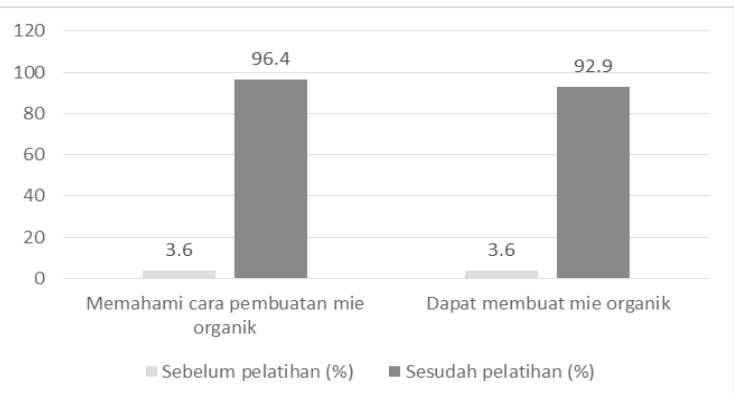

Gambar 2. Grafik Perubahan Pengetahuan dan Keterampilan Peserta Pelatihan Pembuatan Mie Organik

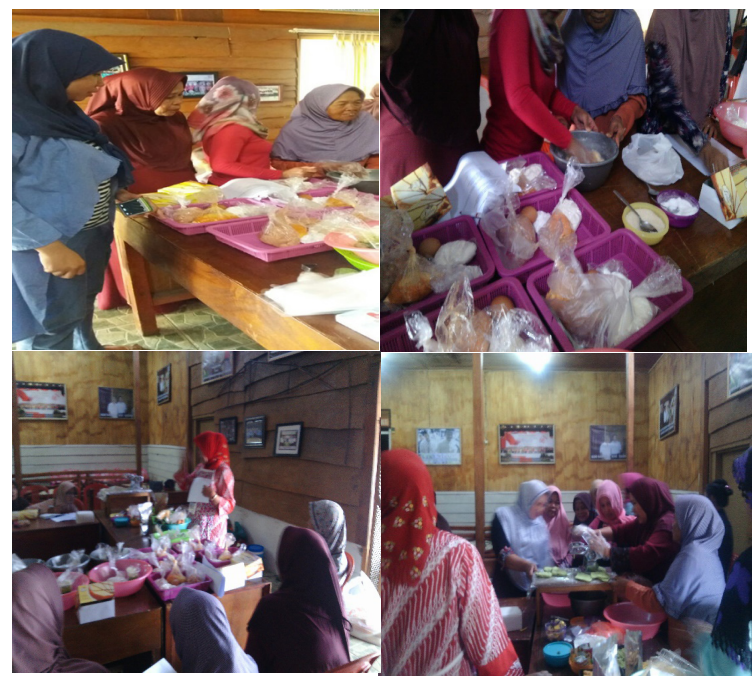

Gambar 2. Kegiatan Pelatihan Pembuatan Mie Organik

2. Fasilitator, Pemateri (Pakar dan Praktisi) dan Pendamping

a. Metode Pembelajaran

b. Metode pembelajaran dilaksanakan secara Partisipatif mulai dari awal sampai akhir kegiatan. Pembela-jaran diawali dengan kegiatan ceramah mengenai nilai tambah dari kegiatan pengolahan mie berbahan baku sayur organik, serta peluang usaha mie organik. Setelah itu dilanjutkan dengan praktek pembuatan mie organik.

c. Metode Fasilitasi

Metode fasilitasi tentu saja melibatkan masyarakat, dimana dengan adanya kegiatan PKM ini berusaha mempertemukan antara praktisi, aparat desa yang terkait dengan anggota PKK. Melalui kegiatan ini, 
diperoleh hasil bahwa kepala Desa Cibodas berjanji akan memfasilitasi alat produksi pembuatan mie dan juga akan mencoba memfasilitasi kegiatan pemasaran bekerjasama dengan beberapa tempat wisata yang ada di Desa Cibodas.

d. Materi Pembelajaran

Materi pembelajaran diberikan sesuai dengan kebutuhan dan teritegrasi, artinya materi yang diberikan berupa modul cara membuat mie organik yang disajikan dalam bahasa yang mudah dipahami dan ringkas padat. alur pembelajaran dapat diikuti dengan baik oleh peserta pelatihan.

e. Alat Bantu Pembelajaran

Alat bantu sudah terintegrasi, langsung, juga dengan menggunakan audio visual, yaitu menampilkan video cara pembuatan mie organik melalui proyektor.

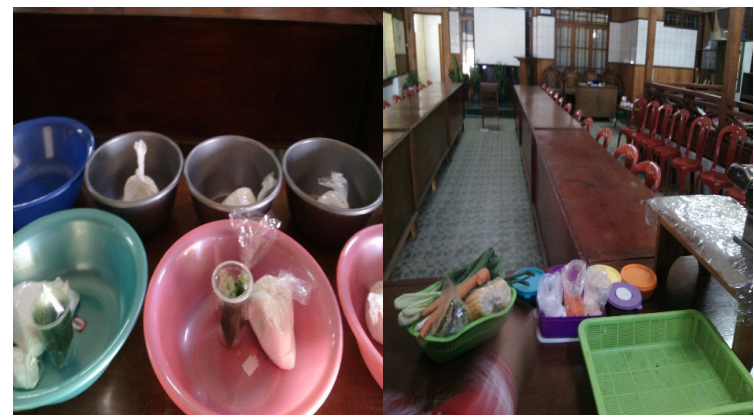

Gambar 3. Alat dan Bahan yang Digunakan dalam Pembuatan Mie Organik

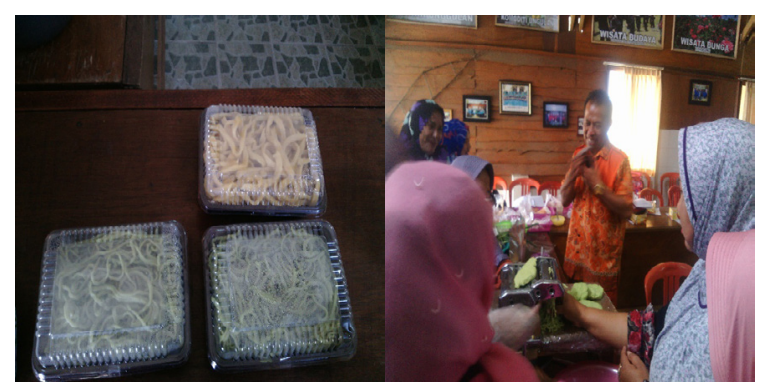

Gambar 4. Mie Organik yang Dihasilkan Peserta Pelatihan (Kiri), Pendampingan oleh Kepala Desa Cibodas (Kanan)

\section{PENUTUP}

Kegiatan PKM ini telah memberikan perubahan pada aspek pengetahuan dan keterampilan peserta dalam meningkatkan nilai tambah produk sayuran organik melalui kegiatan pengolahan mie organik. Dukungan dari pemerintah dilakukan melalui dukungan Kepala Desa Cibodas untuk mengembangkan beragam produk olahan dari sayur organik sebagai produk unggulan Desa Cibodas. Untuk menunjang keberhasilan program maka dukungan dari berbagai pihak, terutama dalam hal penguatan kelembagaan dan pemasaran produk olahan berbahan baku sayur organik.

\section{UCAPAN TERIMA KASIH}

Terima kasih kepada Universitas Padjadjaran yang telah memfasilitasi kegiatan pengabdian kepada masyarakat ini melalui skema Hibah Internal PKM tahun anggaran 2017

\section{DAFTAR PUSTAKA}

Feder, G. dan Savastano, S., 2006. The role of opinion leaders in the diffusion of new knowledge: the casa of integrated pest management. World Development, 34, 1287-1300

Feder, G., Murgai, R. dan Quizon, J.B., 2004a. The acquisition and the diffusion of knowledge: the case of pest management training in farmer field schools, Indonesia. Journal of Agricultural Economics, 55: 217-239.

Godtland, E. M., Sadoulet, E., de Janvry, A., Murgai, R., dan Ortiz, O., 2004. The impact of farmer field schools on knowledge and productivity: a study of potato farmers in Peruvian Andes. Economic Development and Cultural Changes, 53: 63-92.

Subroto, E., Tensiska., Indirto, R. 2014. Peningkatan pengetahuan dan keterampilan dalam upaya mendukung ketahanan pangan di Desa Girijaya dan Mekarjaya, Kecamatan Cikajang, Kabupaten Garut. Jurnal Dharakarya 3(1): 1-4

Zulvera. 2014. Faktor penentu adopsi sistem pertanian sayuran organik dan keberdayaan petani di Provinsi Sumatera Barat. [disertasi].. Bogor: Institut Pertanian Bogor 